\title{
RESEARCH PAPER \\ Sheep and goat grazing diets on an annual Mediterranean grassland containing tall wheatgrass (Thinopyrum ponticum (PODP.))
}

\author{
Giorgio L. Castellaro G., Hernán A. Urra A., Javier A. Hidalgo A., Carla L. \\ Orellana M., and Juan P. Escanilla C. \\ Universidad de Chile, Facultad de Ciencias Agronómicas, Departamento de Producción Animal. Santa \\ Rosa 11315, La Pintana, Santiago, Chile.gicastel@uchile.cl
}

\begin{abstract}
G. Castellaro G., H. Urra A., J. Hidalgo A., C. Orellana M., and J. Escanilla C. 2018. Sheep and goat grazing diets on an annual Mediterranean grassland containing tall wheatgrass (Thinopyrum ponticum (PODP.)). Cienc. Inv. Agr. 45(3):240-250. The development of mixed grazing systems is an interesting alternative for the utilization of rangelands with ecological and/ or economic limitations; therefore, the study of patterns and eating habits of different species in the same grazing area is important. A mixed grazing study was carried out on a Mediterranean

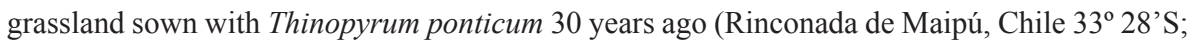
$70^{\circ} 51^{\prime} \mathrm{W}$ ) with the purpose of quantifying the botanical composition, dietary overlap and selectivity indexes of the main grass species consumed by goats and sheep. Trophic behavior was studied in seven young Suffolk Down rams, seven young Merino-Precoz rams and seven young Boer-Criollo bucks grazing together during three grassland phenological stages. During the grassland vegetative stage, diets were mainly composed of annual grasses and forbs. Perennial grasses dominated the animals' diets during the reproductive and dry grassland stages. The diversity of the goats' diets was higher than that of the sheep, demonstrating greater plasticity in their dietary habits. However, in this environment, both species behaved as generalist herbivores. The level of diet overlap between the sheep and goats was high, especially when grazing during the grassland reproductive and dry phenological stages, suggesting potential competition during lower forage quality stages.
\end{abstract}

Keywords: Dietary indexes, microhistology, mixed grazing, small ruminants.

\section{Introduction}

Mixed grazing is a common practice in agricultural systems, which generally have ecological and/or economic constraints that prevent the inclusion of complex forage schemes for improvement. In

Received Aug 04, 2017. Accepted Dec 05, 2018.

Corresponding author: gicastel@uchile.cl these systems, the coexistence of herbivorous species can be explained by food niche specialization as a way to reduce competition among them. When more than one species graze in the same grassland, there may be complementarity diet selection provided that grazing species do not overlap grazing site selection and/or bite selection. Species are known to differ in their grazing patterns and habits, and these differences 
can be complementary; therefore, mixed grazing could result in more animal products per unit area (Animut and Goetsch, 2008). Moreover, knowledge of the herbivore's botanical diet composition in both domestic and wild animals helps to develop conservation and animal management strategies and minimizes grazing impacts (Holechek et al., 2011). These studies are essential for identifying plant species comprising the forage consumed by livestock and are also a useful tool for supplementary diet programs in the case of nutritional deficiency, as well as optimizing the allocation of rangelands for different types of herbivores and/or selecting appropriate grazing systems compatible with the forage resource (Holechek et al., 2011). In Chile, diet studies of domestic animals have been conducted mainly with sheep, whereas the available information for goats is limited (Castellaro, 2006). Both ruminant species are characterized by their marked ability to adapt to different environmental conditions, given their dietary habit diversity (Zanine et al., 2006); however, in arid grazing systems, goats consume more woody forage, feed on a greater number of species and have the ability to change their shrubby diet to an herbaceous one (Mellado et al., 2005). Another difference between these two animal species in relation to their feeding strategies is the goat's ability to adopt a bipedal position and increased lip mobility; therefore, their diets are generally different (Warren et al., 1984). Gramineous species are the main components of sheep diets (Aldezabal et al., 2002; Mellado et al., 2005). Based on these characteristics, this study analyzed the following hypotheses: 1) There is variation in the botanical diet composition of different animal types, depending on the grassland phenological stage; and 2) The extent of diet overlap between the sheep and goats is low, but it is influenced by the grassland phenological stage. The present study objectives were to determine the botanical composition, diet overlap and selectivity index of the main plant species consumed by sheep and goats in three different phenological stages of a naturalized grassland dominated by Thinopyrum ponticum and winter growth therophytes.

\section{Materials and Methods}

The study was carried out in the Small Ruminant and Rangeland Section of the Rinconada Experimental Station ( $33^{\circ} 28^{\prime}$ lat S, $70^{\circ} 51^{\prime}$ long W.; 470 m.o.s.l.) from May 2008 to January 2009. The climate is Mediterranean, with an average annual rainfall of $298.9 \mathrm{~mm}$ (years 1958-2015) concentrated between May and September $(90.3 \%)^{1}$. Soils are of wavy topography and fine sandy loam texture, with an effective depth between $35-70 \mathrm{~cm}$ and dark brown colors (Durixerolls). The study was conducted in an 11.8 ha paddock planted with tall wheatgrass (T. ponticum) 30 years ago, and where the presence of winter growth therophyte genera Bromus, Hordeum and Erodium are common. In this unit, seven Merino Precoz (MP), seven young Suffolk Down rams (S) and seven young Boer-Criollo bucks (BC) grazed together continuously, averaging an animal stocking rate of 2.8 dry sheep equivalent ha-1.

A map of grassland sites was carried out according to soil and vegetation attributes (soil texture, root depth, hydromorphism and plant cover). At each site, botanical composition, plant cover, bare soil and the presence of litter were determined by the "line point intercept" method (Bonham, 1989), using a variable number of transects according to the proportion of the site with respect to the total area evaluated (Etienne et al., 1979). Pasture dry matter availability (DMSP, $\mathrm{kg} \mathrm{ha}^{-1}$ ) associated with each evaluation line was estimated by cutting off the forage in a $0.25 \mathrm{~m}^{2}$ quadrant with a remnant of approximately $3 \mathrm{~cm}$ height. The vegetal material was dehydrated at $70^{\circ} \mathrm{C}$ for $48 \mathrm{~h}$. The values of botanical composition, plant cover, bare soil percentage, litter percentage and pasture dry matter availability from each site were averaged, and this value was weighted according to its proportion in the grassland. This measurement was performed for three grassland phenological

\footnotetext{
${ }^{1}$ Information obtained from the pluviometric register of the Germán Greve Silva Experimental Station ( $33^{\circ} 1^{\prime}$ lat $\mathrm{S}$, $70^{\circ} 50$ ' long. O; 470 m.o.s.1.).
} 
stages: vegetative (August), reproductive (October) and dry (December), which were defined in terms of the development of annual grass species (George and Rice, 2016).

The botanical diet composition was estimated by the microhistological analysis of feces (Sparks and Malechek, 1968; Holechek et al., 2011), which is considered a rapid and detailed quantitative method to identify plant species in herbivore diets (Garnick et al., 2018). Plant reference epidermic patterns of the study area, sampling protocol, preparation and sample analysis were outlined by Castellaro et al. (2007a). The identification of epidermic fragments was made at the genus and species level whenever possible and classified into four groups: annual grasses, perennial grasses, dicotyledonous herbs and shrubs, whose relative frequency was expressed as density using the Fracker and Brischle table (Sparks and Malechek, 1968). Diet diversity was estimated by means of the Shannon-Wiener Index (H) $\left(\mathrm{H}=-\sum \mathrm{P}_{\mathrm{i}} \times \log _{2}\left(\mathrm{P}_{\mathrm{i}}\right)\right)$, expressed as relative diversity $(J)\left(J=H / H_{\text {max }}\right)$, where $P_{i}$ is the proportion of i species in the diet, $\mathrm{H}_{\max }$ is the value of $\mathrm{H}$ if all the species observed had the same frequency $\left(\mathrm{H}_{\max }=\right.$ $\left.\log _{2}(n)\right)$, and $n$ is the number of plant species in each sample (Smith and Smith, 2012). To evaluate the dietary overlap, pairs of MP and S, MP and $\mathrm{BC}$ and $\mathrm{S}$ and $\mathrm{BC}$ individuals were established and maintained throughout the evaluation stages. With the botanical composition results of these pairs, the Kulczynski index $\left(\mathrm{IS}_{\mathrm{K}}\right)\left(\mathrm{IS}_{\mathrm{K}}=\sum 2 \times \mathrm{W}_{\mathrm{i}} / \sum(\mathrm{a}+\mathrm{b})_{\mathrm{i}}\right)$ was calculated, where $\mathrm{W}_{\mathrm{i}}$ is the lowest percentage of a particular plant species when their percentages are compared between two different animal diets and $(a+b)_{i}$ is the sum of these percentages (Oosting, 1956). Finally, the degree of selectivity for the main plant species consumed was quantified by Ivlev's selectivity index $\left(E_{i}\right)\left(E_{i}=\left(D_{i}-P_{i}\right) /\right.$ $\left(D_{i}+P_{i}\right)$ ), where $D_{i}$ is the proportion of $i$ species in the diet and $\mathrm{P}_{\mathrm{i}}$ is the ratio of the same species in the grassland (Krebs, 1989).

To analyze the percentage of the main diet species, the dietary diversity and selectivity indexes of the main plant species consumed were calculated using a split-plot design with a $3 \times 3$ factorial structure, where the main plot was the grassland phenological stage, and the subplot was the animal type. In the case of diet overlap indexes between the different types of animals, in the absence of an individual effect of the type of animal, indexes were calculated using a completely randomized design, considering the phenological stage of the grassland as the only source of variation. All variables were transformed into Bliss degrees and subjected to ANOVA. To detect significant differences between treatments, data were subjected to a multiple comparisons test ( $\mathrm{SNK}, \mathrm{P} \leq 0.05$ ) (Kaps and Lamberson, 2004). The statistical software used was STATGRAPHICS Centurion XV.II.

\section{Results}

Between the vegetative and dry phenological stages, a plant cover decrease and a litter proportion increase were observed. The bare soil percentage reached its maximum value during the reproductive stage, whereas the least DMSP was estimated with a weighted value of $3,400 \mathrm{~kg}$ $\mathrm{ha}^{-1}$ during the vegetative stage. In the reproductive and dry phenological stages of the grassland, DMSP increased by 5,250 and 5,064 $\mathrm{kg} \mathrm{ha}^{-1}$, respectively (Table 1). The grassland botanical composition was dominated by perennial grasses, among which $T$. ponticum represented over $40 \%$ in all phenological stages. This group contribution increased during grassland development and remained dominant. Another important group was the annual dicotyledonous herbs, especially Medicago polymorpha and Melilotus sp., during the vegetative and reproductive phenological stages; their contribution as a group increased to more than $16 \%$. However, during the dry stage, the contribution of these leguminous herbs was minimal, in contrast with that of Matricaria cotula, which was important in this phenological stage. Additionally, we identified species of the Hordeum and Bromus genera, especially during the vegetative and reproductive phenological stages (Table 1). 
During the vegetative stage and within the annual grasses, species of the Hordeum genus were the most important, with the highest percentage especially in the $\mathrm{S}$ diet, which was significantly different $(\mathrm{P} \leq 0.05)$ than its contribution to the MP and $\mathrm{BC}$ diets. During the reproductive and dry phenological stages, these species contributions decreased, making the contribution difference between animal types similar, with a significant interaction $(\mathrm{P} \leq 0.05)$ between the herbivore type and the grassland phenological stage (Table 2). Another important annual grass was Bromus hordeaceus, but unlike Hordeum spp., no sig- nificant differences attributed to the animal type (Table 2) were shown $(\mathrm{P}=0.062)$. The proportion of that species in the diets was significantly higher $(\mathrm{P} \leq 0.05)$ during the vegetative stage $(11.2 \%)$ but decreased in the reproductive $(4.9 \%)$ and dry stages $(6.0 \%)$ (Table 2).

With respect to perennial grasses, the presence of Festuca arundinacea in the diet was similar in the two sheep breeds, which was significantly higher $(\mathrm{P} \leq 0.05)$ than that estimated in the goat diets, especially when goats were compared with MP sheep (Table 2). During the growing season,

Table 1. Grassland botanical composition, plant cover, litter, bare soil and dry matter availability in three phenological stages.

\begin{tabular}{|c|c|c|c|}
\hline \multirow{2}{*}{ Vegetal species (\%) } & \multicolumn{3}{|c|}{ Grassland phenological stage } \\
\hline & Vegetative & Reproductive & Dry \\
\hline \multicolumn{4}{|l|}{ Annual grasses } \\
\hline Bromus hordeaceus & 4.54 & 2.05 & 0.00 \\
\hline Hordeum marinum & 2.52 & 4.40 & 4.40 \\
\hline Hordeum murinum & 6.95 & 8.56 & 0.65 \\
\hline Other annual grasses & 3.55 & 4.89 & 4.26 \\
\hline Subtotal & 17.56 & 19.90 & 9.31 \\
\hline \multicolumn{4}{|l|}{ Perennial grasses } \\
\hline Festuca arundinacea & 0.70 & 4.17 & 1.16 \\
\hline Phalaris aquatica & 0.38 & 0.11 & 1.42 \\
\hline Thinopyrum ponticum & 40.45 & 42.08 & 65.35 \\
\hline Subtotal & 41.53 & 46.36 & 67.93 \\
\hline \multicolumn{4}{|l|}{ Annual herbs } \\
\hline Erodium malacoides & 6.97 & 0.41 & 0.00 \\
\hline Erodium moschatum & 2.99 & 1.84 & 0.00 \\
\hline Matricaria cotula & 3.68 & 12.49 & 11.66 \\
\hline Medicago polymorpha & 12.75 & 12.15 & 0.00 \\
\hline Melilotus sp. & 8.15 & 4.69 & 0.00 \\
\hline Other annual herbs & 5.60 & 1.84 & 10.6 \\
\hline Subtotal & 40.15 & 33.41 & 22.26 \\
\hline Perennial herbs & 0.77 & 0.32 & 0.51 \\
\hline Plant cover $(\%)$ & 84.30 & 55.72 & 47.44 \\
\hline Litter (\%) & 13.70 & 37.25 & 48.39 \\
\hline Bare soil (\%) & 2.01 & 7.03 & 4.17 \\
\hline Dry matter availability $\left(\mathrm{kg} \mathrm{ha}^{-1}\right)$ & 3,400 & 5,250 & 5,064 \\
\hline
\end{tabular}


Table 2. Diet botanical composition in Suffolk sheep, Merino sheep and Boer-Criollo goats in different grassland phenological stages.

\begin{tabular}{|c|c|c|c|c|c|c|c|c|c|}
\hline \multirow{3}{*}{ Species Groups } & \multicolumn{9}{|c|}{ Grassland phenological stage } \\
\hline & \multicolumn{3}{|c|}{ Vegetative } & \multicolumn{3}{|c|}{ Reproductive } & \multicolumn{3}{|c|}{ Dry } \\
\hline & Suffolk & Merino & Goat & Suffolk & Merino & Goat & Suffolk & Merino & Goat \\
\hline \multicolumn{10}{|l|}{ Annual grasses } \\
\hline Hordeum spp. & 37.9 & 24.5 & 23.9 & 5.3 & 6.4 & 6.5 & 6.1 & 4.3 & 5.3 \\
\hline Bromus hordeaceus & 11.3 & 8.8 & 13.5 & 7.3 & 4.7 & 6.0 & 4.3 & 4.5 & 5.8 \\
\hline Other annual grasses & 9.4 & 8.0 & 5.7 & 1.5 & 3.1 & 2.9 & 2.9 & 3.2 & 1.1 \\
\hline Subtotal & 58.6 & 41.3 & 43.1 & 14.1 & 14.2 & 15.4 & 13.3 & 12.0 & 12.2 \\
\hline \multicolumn{10}{|l|}{ Perennials grasses } \\
\hline Thinopyrum ponticum & 5.4 & 5.5 & 12.3 & 21.6 & 27.8 & 24.0 & 12.9 & 10.2 & 11.3 \\
\hline Festuca arundinacea & 5.5 & 6.8 & 7.5 & 36.9 & 40.5 & 28.6 & 50.0 & 52.3 & 41.5 \\
\hline Other perennial grasses & 0.0 & 0.0 & 0.0 & 0.1 & 0.1 & 0.3 & 0.2 & 0.2 & 0.3 \\
\hline Subtotal & 10.9 & 12.3 & 19.8 & 58.5 & 68.3 & 52.8 & 63.1 & 62.7 & 53.0 \\
\hline \multicolumn{10}{|l|}{ Annual herbs } \\
\hline Erodium cicutarium & 0.2 & 0.4 & 2.0 & 1.1 & 0.5 & 0.6 & 0.2 & 0.6 & 0.5 \\
\hline Erodium moschatum & 2.1 & 5.3 & 4.6 & 3.6 & 1.2 & 3.3 & 0.8 & 0.4 & 1.4 \\
\hline Other herbs & 28.2 & 40.8 & 30.6 & 22.8 & 15.5 & 27.4 & 22.4 & 24.3 & 31.0 \\
\hline Subtotal & 30.5 & 46.4 & 37.1 & 27.4 & 17.2 & 31.4 & 23.5 & 25.3 & 32.8 \\
\hline \multicolumn{10}{|l|}{ Shrubs } \\
\hline Acacia caven & 0.0 & 0.0 & 0.0 & 0.0 & 0.2 & 0.4 & 0.1 & 0.0 & 1.9 \\
\hline
\end{tabular}

the average percentage of this species in the animal diets was $6.6 \%$, increasing by $35.3 \%$ in the reproductive phenological stage and reaching $47.9 \%$ during the dry phenological stage, which was a significant increase $(\mathrm{P} \leq 0.05)$. In this case, no relevant interaction between the animal type and the grassland phenological stage was detected $(\mathrm{P}=0.157)$. The presence of $T$. ponticum in diets during the phenological reproductive stage (11.5\%) and dry stage (24.4\%) did not differ between the animal types; however, it did so during the vegetative stage, where the goat diets contained a significantly higher percentage $(\mathrm{P} \leq 0.05)$ of this species compared with the diets of both sheep breeds. This denotes a significant interaction $(\mathrm{P} \leq 0.05)$ between the phenological stage and the animal type. The contribution of dicotyledonous forbs was significantly higher $(\mathrm{P} \leq 0.05)$ during the vegetative stage $(38.0 \%)$ compared to other phenological stages. However, it was not possible to identify a particular species, with the exception of the Erodium genus, which accounted for less than $6.0 \%$. In this phenological stage, forbs were important, especially in MP diets, while in the reproductive and dry phenological stages, this species was more important in the $\mathrm{BC}$ diets, reflecting a significant interaction $(\mathrm{P} \leq 0.05)$ between the phenological stage and animal type (Table 2). Woody species were practically undetected in animal diets, except for some traces of Acacia caven, especially in the $\mathrm{BC}$ diet during the reproductive and vegetative phenological stages.

Diet diversity was significantly higher in $\mathrm{BC}$ than in both sheep breeds $(\mathrm{P} \leq 0.05)$, which shared a similar diversity (Table 3 ). When comparing the three phenological stages, diet diversity was observed to be significantly lower in all of the animal types $(\mathrm{P} \leq 0.05)$ during the dry phenological stage than that in the vegetative and reproductive phenological stages. The interaction between the phenological stage and animal type was not significant enough account for the variability observed in diet diversity $(\mathrm{P}=0.140)$.

Kulczynski's dietary overlap index was high in all the grassland phenological stages, especially between the sheep breeds during the vegetative stage when compared with the dry phenological stage $(\mathrm{P} \leq 0.05)$, where the dietary overlap was greater (Table 4). 
Table 3. Relative diversity of diets in sheep and goats in three grassland phenological stages, measured through the index of Shannon-Wiener (average \pm standard deviation).

\begin{tabular}{lcccc}
\hline \multirow{2}{*}{ Grassland phenological stage } & \multicolumn{3}{c}{ Animal type } & \multirow{2}{*}{ Average } \\
\cline { 2 - 4 } & Merino & Suffolk & Boer-Criollo goats & \\
\hline Vegetative & $0.764 \pm 0.03$ & $0.741 \pm 0.07$ & $0.837 \pm 0.06$ & $0.781^{\mathrm{A}}$ \\
Reproductive & $0.710 \pm 0.03$ & $0.770 \pm 0.08$ & $0.763 \pm 0.03$ & $0.748^{\mathrm{A}}$ \\
Dry & $0.667 \pm 0.07$ & $0.680 \pm 0.07$ & $0.689 \pm 0.07$ & $0.689^{\mathrm{B}}$ \\
Average & $0.714^{\mathrm{a}} \pm 0.09$ & $0.731^{\mathrm{ab}} \pm 0.06$ & $0.763^{\mathrm{b}} \pm 0.09$ & \\
\hline
\end{tabular}

Different letters between columns or between rows indicate significant differences $(\mathrm{P} \leq 0.05)$ according to SNK multiple comparison test.

Table 4. Kulczynski's dietary overlap index for sheep and goats in different grassland phenological stages.

\begin{tabular}{|c|c|c|c|c|}
\hline \multirow{2}{*}{ Animal pair } & \multicolumn{2}{|c|}{ Grassland phenological stage } & \multirow{2}{*}{ Dry } & \multirow{2}{*}{ Average } \\
\hline & Vegetative & Reproductive & & \\
\hline Goat - Merino sheep & $0.794^{\mathrm{a}}$ & $0.781^{\mathrm{a}}$ & $0.815^{\mathrm{a}}$ & 0.797 \\
\hline Goat - Suffolk sheep & $0.755^{\mathrm{a}}$ & $0.835^{\mathrm{a}}$ & $0.805^{\mathrm{a}}$ & 0.798 \\
\hline Merino sheep - Suffolk sheep & $0.763^{\mathrm{a}}$ & $0.808^{\mathrm{ab}}$ & $0.847^{\mathrm{b}}$ & 0.806 \\
\hline
\end{tabular}

Different letters between columns indicate significant differences $(\mathrm{P} \leq 0.05)$ according to $\mathrm{SNK}$ multiple comparison test.

During the vegetative stage, the S sheep had the greatest selectivity for Hordeum species $\left(\mathrm{E}_{\mathrm{i}}=0.59\right)$, which was significantly different from that in MP sheep and $\mathrm{BC}$ goats $(\mathrm{P} \leq 0.05)$ where the Hordeum average selection was 0.42 . In the reproductive phenological stage, the $E_{i}$ of the grass was lower, ranging from a selection to a rejection situation, reaching an average value of -0.38 and with no significant differences among the animal types $(\mathrm{P}=0.648)$. During the dry phenological stage, this situation was reversed, and the $\mathrm{E}_{\mathrm{i}}$ index of this species group showed positive values but of a lower magnitude than the selectivity obtained during the vegetative stage. In addition, significant differences among the different animal types $\left(E_{i}=0.06,0.15\right.$ and 0.30 were observed in this stage for the $\mathrm{S}$ and MP sheep and $\mathrm{BC}$ goats, respectively), thereby demonstrating a significant interaction between the grassland phenological stage and the animal type $(\mathrm{P} \leq 0.05)$ (Figure 1).

B. hordeaceus was also selected by all of the animals, but its $\mathrm{E}_{\mathrm{i}}$ presented significant differences $(\mathrm{P} \leq 0.05)$ among the animal types; MP sheep presented the lowest selectivity in all of the phenological stages, whereas in S sheep and BC goats, the $\mathrm{E}_{\mathrm{i}}$ was similar. A significant difference in the $B$. hordeaceus selectivity index $(\mathrm{P} \leq 0.05)$ was detected in all the grassland phenological stages, with the lowest values obtained in the vegetative stage. In $\mathrm{BC}$ goats, $\mathrm{E}_{\mathrm{i}}$ had a value of 0.48 , while in MP and S sheep, it was 0.31 and 0.38 , respectively. During the reproductive stage, $\mathrm{E}_{\mathrm{i}}$ values of this species tended to increase, reaching 0.55 in S sheep, 0.34 in MP sheep, and 0.46 in $\mathrm{BC}$ goats. In the dry phenological stage, the selectivity index for this plant species was higher, with a value of 1.0 for S sheep and $\mathrm{BC}$ goats and 0.71 for MP sheep. The interaction between animal types and phenological stages was not significant $(\mathrm{P}=0.645)$ (Figure 1).

F. arundinacea was selected by all animal types, but no significant differences among them were found $(\mathrm{P}=0.311)$. However, when comparing the selectivity index of this plant species in each phenological stage, a significant difference was found $(\mathrm{P} \leq 0.05)$. Values were similar in the veg- 


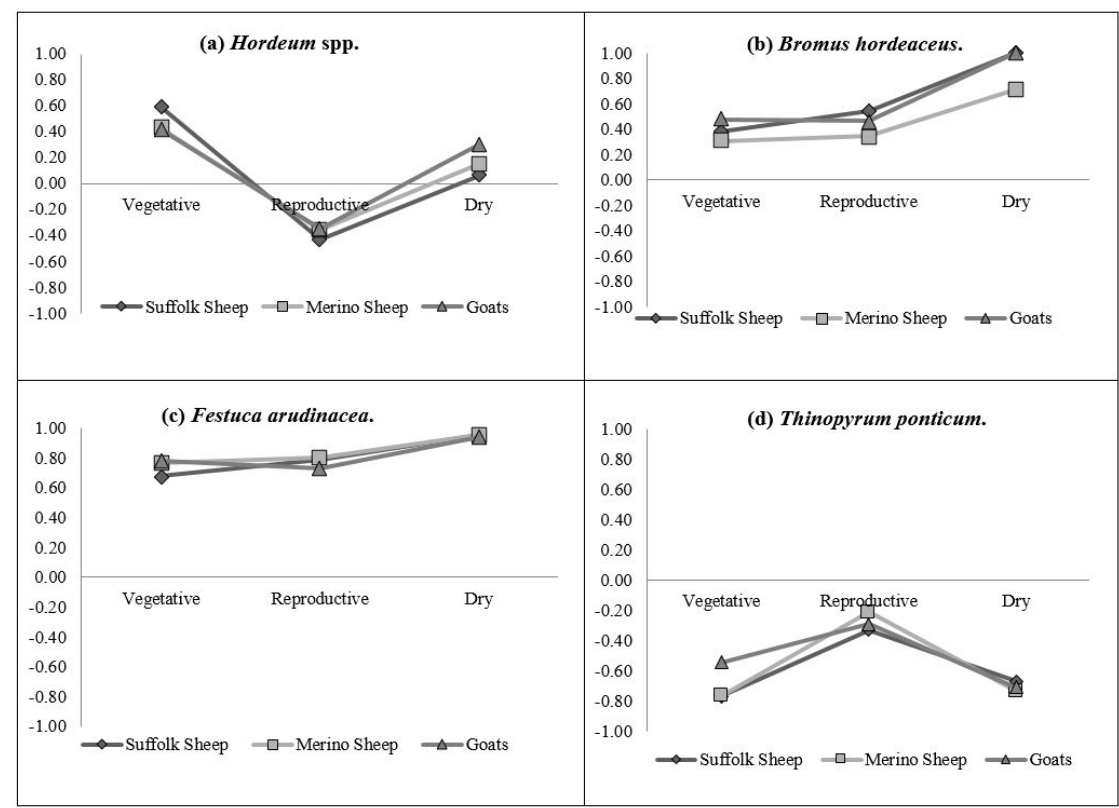

Figure 1. Selectivity index of (a) Hordeum spp.; (b) Bromus hordeaceus; (c) Festuca arundinacea and (d) Thinopyrum ponticum in Suffolk sheep, Merino sheep and Boer-Criollo goats in different grassland phenological stages.

etative and reproductive stages with an average value of 0.76 ; however, in the dry phenological stage, the selectivity index of this plant species was significantly higher $(\mathrm{P} \leq 0.05)$, with an average value of 0.95 . The interaction between the grassland phenological stage and the animal type was not significant $(\mathrm{P}=0.320)$ (Figure 1).

T. ponticum was rejected by all animal types and in all grassland phenological stages, especially during the reproductive and dry stages. In the vegetative stage, $\mathrm{BC}$ goats showed less rejection of this plant species in comparison to that of both $\mathrm{S}$ and MP sheep. In the subsequent phenological stages, there were no differences among the animal types, which indicated the existence of a significant interaction $(\mathrm{P} \leq 0.05)$ between the grassland phenological stage and the animal type (Figure 1).

\section{Discussion}

The grassland phenological development explains the plant cover decrease as well as the litter increase. The lack of rainfall and the onset of senescence, loss and decomposition of annual plant species during the reproductive and dry phenological stages explain the litter increase in the study area in those stages. In all the phenological stages, the DMSP was higher in places where $T$. ponticum dominated and lower in others dominated by therophytes. The observed increase in this variable may be explained by the increase in plant cover and dry matter accumulation in the reproductive and dry stages as a product of grassland growth. The annual grass decrease and dicot contribution during the dry phenological stage were probably due to animal intake and an accelerated senescence of these species in this phenological stage - a characteristic of therophyte plants (George and Rice, 2016).

The differences regarding Hordeum spp. intake between the sheep breeds during the vegetative stage were also reported by Du Toit (1998) and Osoro et al. (1999), attributing such behavior to the intake capacity differences associated with body size, maintenance requirements, productive potential 
and the environmental adaptation degree of the $\mathrm{S}$ breed, as well as the plant species availability. The subsequent intake decline of Hordeum spp. in the reproductive and dry phenological stages for all animal types was similar to that found by Castellaro et al. (2007b) in alpaca diet composition in annual Mediterranean grasslands; intake decline may be a response to the decline in of this plant species in the grassland botanical composition. The same phenomenon can explain the $B$. hordeaceus content in the diet of all the animals in relation to the species availability in the grassland, which decreased systematically towards the dry phenological stage. The increased presence of $F$. arundinacea in the diet of all the animals as the grassland matured could be due to the lignin content of $F$. arundinacea, which is positively related to ingestion (contrary to expected) and could be explained by the presence of alkaloids in young plants of this species, which tend to decrease as the plant lignifies at maturity (Pujol, 1998). The greater contribution of $T$. ponticum during the reproductive stage could be attributed to greater digestibility, a higher nitrogen content, and a low fiber content as measured in this species during the spring, after which quality is considerably reduced (Alonso et al., 2000). This suggests that the animals consumed the largest proportion of this species at the time of greater nutritional value (Ricci et al., 2006). The increase in forb species intake during the vegetative stage by MP sheep can be explained by the consumption of Erodium moschatum in that stage. George and Rice (2016) showed that the percentage of crude protein and the digestibility of this species decreased as it matured, which could account for the highest proportion of forbs in the animal's diet when their nutritional value was higher.

A greater diversity in the diet of goats than the diet of sheep was also found by Somlo et al. (1994). Such behavior should provide goats with greater plasticity in their dietary habits and a greater trophic niche range and, thus, a high degree of adaptation to food type variations and availability throughout the year. This is consistent with observations by De
Gea et al. (2005) and Castro and Fernandez-Nuñez (2016). However, both animal species behave as generalist herbivores, adapting their preferences to seasonally available botanicals (Holechek et al., 2011; Osoro et al., 2013). The lower dietary diversity presented by all the animals in the dry phenological stage is a result of the lower grassland species richness and the lower nutritional quality during that period (George and Rice, 2016).

No differences in the diet overlap between both sheep breeds and goats that might be attributed to the grassland phenological stage could be found. Nevertheless, Kulczynski's index values indicated potential competition between these herbivores, particularly among the breeds of sheep, for more palatable plant species, especially in those seasons when the grassland quality decreased. This behavior is similar to that presented by Aldezabal et al. (2002) and Castellaro et al. (2004). Concordant results were found by Warren et al. (1984) when comparing dietary overlap between sheep and goats in three different environments, where diet overlap between both ruminant species was 0.81 . García-González and Cuartas (1989), working with sheep and goat diets, found a diet overlap value of 0.71 , noting that such a value would be of great magnitude. Celaya et al. (2007) observed an average of diet overlap value between sheep and goats of 0.63 (rank of variation between 0.56 and 0.72 ), depending on the season it was assessed. However, Castro and Fernandez-Nuñez (2016) reported a lower diet overlap (0.16-0.36) in Mediterranean grazing lands, where the shrub component was dominant. Mphinyane et al. (2015) reported a $37.5 \%$ average value for diet overlap between sheep and goats, with higher values during the dry season, reflecting seasonal influence as animals shift dietary focus and when the potential forage selections are restricted by limited species diversity and availability.

The selection of the Hordeum species by these animals was also observed by Gurung et al. (1994) in Merino sheep and Angora goats in the Mediterranean climatic zone of southern Australia. Castellaro 
et al. (2004), in a study with alpacas, confirmed that the selectivity values of Hordeum spp. were high in the active grassland growth stage, but these values decreased in later developmental stages and were also associated with the developmental characteristics of different species. The trend of $B$. hordeaceus selection observed in this study coincides with that reported by other researchers working with MP sheep in Mediterranean annual grasslands (Castellaro, 2006). Sierra et al. (2006), studying Corriedale sheep grazing on a grassland dominated by $T$. ponticum, $F$. arundinacea and Distichlis spp., observed a greater selection for the latter species, followed by $F$. arundinacea, which was reported to be consumed in the ibex diet, indicating that this ruminant has a high capacity to digest the fibrous components of the cell wall (Soriguer et al., 1994). In the same study by Sierra et al. (2006), T. ponticum tended to be rejected under both high and low availability. In the current study conditions, T. ponticum presented an average height over $1.5 \mathrm{~m}$ in the dry phenological stage, meaning the tender leaves were out of reach for the animals, thus reducing its selection. The situation described above is explained by García-González and Cuartas (1992a; 1992b) and Papachristou (1997), who observed that animals increased their preference for some species whenever they were available.

The main conclusions are the following. Under the study conditions during the time when this study was carried out, the sheep and goats behaved as generalist herbivore grazers; however, the goats had a more diverse diet than the sheep, giving the latter ones greater plasticity in their dietary habits. The degree of diet overlap between the sheep and goats was high, suggesting potential competition between these herbivores for the most palatable grassland plant species, especially in those seasons when plant quality decreased. Therefore, mixed grazing in those seasons would not be advisable. $B$. hordeaceus and $F$. arundinacea were highly selected by sheep and goats, regardless of their phenological stage, whereas $T$. ponticum was a rejected species. In the case of Hordeum spp., rejection occurred during the reproductive stage.

\section{Resumen}

G. Castellaro, H. Urra, J. Hidalgo, C. Orellana, y J.P. Escanilla. 2018. Dietas de ovinos y caprinos pastoreando en pastizales mediterráneos anuales con agropiro (Thinopyrum ponticum (PODP.)). Cienc. Inv. Agr. 45(3):240-250. El desarrollo de sistemas mixtos de pastoreo puede ser una alternativa interesante para la utilización de pastizales con limitaciones ecológicas y/o económicas, por lo que es importante el estudio de patrones y hábitos alimenticios de diferentes especies en la misma área de pastoreo. Con el proproposito de cuantificar la composición botánica de la dieta, la sobreposición dieratia e índices de selectividad de las principales especies consumidas por caprinos y ovinos, se realizó un estudio de pastoreo mixto sobre un pastizal mediterráneo sembrado con Thinopyrum ponticum hace 30 años (Rinconada de Maipú, Chile 3328'S; 7051'W). Se estudió el comportamiento trófico de siete carnerillos Suffolk Down, siete carnerillos Merino Precoz y siete chivitos Boer-Criollo, que pastorearon juntos durante tres etapas fenológicas del pastizal. En la etapa vegetativa del pastizal, las dietas estuvieron compuestas principalmente de pastos y dicotiledóneas anuales. Los pastos perennes dominaron las dietas de los animales durante las etapas reproductiva y seca del pastizal. La diversidad de dietas de los caprinos fue mayor que la de ovinos, proporcionándole a estos una mayor plasticidad en sus hábitos alimenticios. Sin embargo, en este ambiente ambas especies se comportan como herbívoros generalistas. El nivel de superposición dietaria entre ovinos y caprinos fue alto, especialmente durante las etapas reproductiva y seca de los pastizales, lo que sugiere una competencia potencial durante la época en que la calidad nutritiva del forraje es menor.

Palabras clave: Índices dietarios, microhistología, pastoreo mixto, pequeños ruminates. 


\section{Reference}

Aldezabal, A., R. García-González, D. Gómez, and F. Fillat. 2002. El papel de los herbívoros en la conservación de los pastos. Ecosistemas 2002/3. http://www.aeet.org/ecosistemas/investigacion6. htm (accessed 20 May. 2009).

Alonso, S.I., J.A Fernandez, C.I Borrajo, and H.E Echeverria. 2000. Cambios en producción y calidad del forraje otoño-invernal por el agregado de nitrógeno en materiales genéticos de Agropiro. Ciencia del Suelo 18(2):115-124.

Animut G., and A.L. Goetsch. 2008. Co-grazing of sheep and goats: Benefits and constraints. Small Ruminant Research 77:127-145.

Bonham C.D. 1989. Measurements for terrestrial vegetation. John Wiley and Sons, New York, USA. 338p.

Castellaro, G., T. Ullrich, B. Wackwitz, and A. Raggi. 2004. Composición botánica de la dieta de alpacas (Lama pacos L.) y llamas (Lama glama L.) en dos estaciones del año, en praderas Altiplánicas de un sector de la Provincia de Parinacota, Chile. Agricultura Técnica (Chile) 64(4):353-364.

Castellaro, G. 2006. Importancia de evaluar las dietas de ungulados en pastoreo. II. Composición del consumo de algunos ungulados sudamericanos domésticos y silvestres, interpretación de la composición botánica y medidas de competencia potencial entre distintas especies. Avances en Producción Animal 31(1-2):17-34.

Castellaro, G., F. Squella, T. Ullrich, F. León, and A. Raggi. 2007a. Algunas técnicas microhistológicas utilizadas en la determinación de la composición botánica de dietas de herbívoros. Agricultura técnica. Chile 67(1):86-93.

Castellaro, G., F. Squella, F. Leon and A. Raggi. 2007b. Botanical Composition of Alpaca (Lama pacos L.) Diet in a Central Mediterranean Range of Chile. Chilean. J. Agric. Res 68(2):136-145.

Castro, M., and E. Fernandez-Nuñez. 2016. Seasonal grazing of goats and sheep on Mediterranean mountain rangelands of northeast Portugal. Livestock Research for Rural Development 28 (5): Article \#91. http://www.lrrd.org/lrrd28/5/ cast28091.html (accessed 22 Jun. 2017).
Celaya, R., M. Oliván, L.M.M. Ferreira, A. Martínez, U. García, and K. Osoro. 2007. Comparison of grazing behaviour, dietary overlap and performance in nonlactating domestic ruminants grazing on marginal heathlands areas. Livest Sci 106:271-281.

De Gea, G.S., A.M. Petryna, A. Mellano, A. Bonvillani, and P. Turiello P. 2005. Herramientas para mejorar la producción y la productividad de los hatos. Pp. 89-111. In: De Gea, G.S., A.M. Petryna, A. Mellano, A. Bonvillani, and P. Turiello. El ganado caprino en la Argentina. Cap. 3. $1^{\mathrm{a}}$ ed., Río Cuarto, Argentina. 195 p.

Du Toit, P.C.V. 1998. A comparison of the diets selected by Merino and Dorper sheep on three range types of the Karoo, South África. Archivos de Zootecnia 47:21-32.

Etienne, M., E. Caviedes, and D. Contreras. 1979. Un nuevo enfoque en la evaluación de la productividad de las praderas. Tomo II. p. 1-12. In: Instituto de Investigaciones en Recursos Naturales (IREN). Seminario Metodología para el Desarrollo de Zonas en Desertificación, La Serena. 8 de mayo de 1978. IREN, CORFO, Santiago Chile.

García-González, R., and P.A. Cuartas. 1992a. Feeding strategies of Spanish Wild Goat in the Cazorla Sierra (Spain). Ungulates 91:167-170.

García-González, R., and P.A. Cuartas. 1992b. Food habits of Capra pyrenaica, Cervus elaphus and Dama dama in the Cazorla Sierra (Spain). Mammalia 56(2):195-202.

García-González, R., and P. A. Cuartas. 1989. Comparison of the diets of the wild goat (Capra pyrenaica), domestic goat (Capra hircus), mouflon (Ovis musimon) and domestic sheep (Ovis aries) in the Cazorla mountain range. Acta Biológica Montana 9:123-132.

Garnick, S., P. S. Barboza, and J. W Walker. 2018. Assessment of Animal-Based Methods Used for Estimating and Monitoring Rangeland Herbivore Diet Composition. Rangeland Ecology \& Management 71(2018):449-457.

George, M. R., and K. Rice. 2016. Plant Growth and Development. In: M.R. George (Ed.). Ecology and Management of Annual Rangelands. Davis, CA: Department of Plant Science. Pgs. 73-95. 
Gurung, N. K., O. A. Jallow, B. A. McGregor, M. J. Watson, B. K. M. H. Mcllroy, and J.H.G. Holmes. 1994. Complementary selection and intake of annual pastures by sheep and goats. Small Ruminant Research 14(1994):185-192.

Holechek, J.L., R.D. Pieper, and C.H. Herbel. 2011. Range Managment, principles and practices. 6th edition. Prentice Hall, Boston. 587 p.

Kaps, M., and W. Lamberson. 2004. Estimation of parameters. Pp 56-64. In: Biostatistics for Animal Science. Chap 5. CABI Publishing. 444 p.

Krebs, C.J. 1989. Ecological methodology. Harper Collins Publisher, New York, New York. 654 p.

Mellado, M., A. Olvera, A. Quero, and G. Mendoza. 2005. Diets of Prairie dogs, goats, and sheep on a Desert Rangeland. R. Ecology and Management 58(4):373-379.

Mphinyane, W.N., G. Tacheba, and J. Makore. 2015. Seasonal diet preference of cattle, sheep and goats grazing on the communal grazing rangeland in the Central District of Botswana. African Journal of Agricultural Research. 10(29):27912803.

Osoro, K., M. Oliván, R. Celaya, and A. Martínez. 1999. Effects of genotype on the performance and intake characteristics of sheep grazing contrasting hill vegetation communities. J. Animal Science 69:419-426.

Osoro, K., L.M.M. Ferreira, U. García, B.M. Jáuregui, A. Martínez, R. Rosa García, and R. Celaya. 2013. Diet selection and performance of sheep and goats grazing on different heathland vegetation types. Small Ruminant Research 109:119-127.

Oosting, H. J. 1956. The study of plant communities. 2nd Ed. W. H. Freeman Co. 440 p.e

Papachristou, T. G. 1997. Foraging behaviour of goats and sheep on Mediterranean kermes oak shrublands. Small Ruminant Research 24:85-93.

Pujol, P.M. 1998. Ingestibilidad de las gramíneas. pp 201-219. In: Pujol P., M. 1998. Gramíneas Aplicaciones Agronómicas. Universidad Politécnica de Catalunya (ed), Barcelona, España. 219 p.
Ricci, P., A. Romera, J. Burges, H. Fernández, and C Cangiano. 2006. Consumo y digestibilidad in vivo de heno y henolaje de Agropiro en tres estados fenológicos. Revista Argentina de Producción Animal. 26, Supl. 1. http://www.aapa.org.ar/ congresos/2006/NaPdf/NA58.pdf.

Sierra, P., M.S. Cid, M. A. Brizuela, and G. Cendoya, 2006. Selección de especies y consumo relativo de láminas foliares por ovinos en una pastura dominada por agropiro con dos estructuras de canopeo. Instituto Nacional de Tecnología Agropecuaria (INTA). http://www.inta.gov.ar/balcarce/info/documentos/posters/6/sierra.htm.

Smith, R.L., and T.M. Smith. 2012. Elements of Ecology, 8th Edition. Pearson. Boston, USA, 612 p.

Somlo, R., G. Bonvissuto, A. Pelliza-Sbriller, N. Bonino, and E. Tecso De Moricz. 1994. La influencia de la condición del pastizal sobre la dieta estacional de los herbívoros y el pastoreo múltiple, en Sierras y Mesetas Occidentales de Patagonia. Buenos Aires. In: Revista Argentina de Producción Animal 14(3-4):187-207.

Soriguer, R.C., P. Fandos, T. Martínez, B. Garcia, and A. García. 1994. Las plantas y los herbívoros: la abundancia de las plantas, su calidad nutricional y la dieta de la cabra montes. pp. 71-92. In: Int. Género Capra en Europa, Ronda (Málaga), 1992. Agencia de Medio Ambiente, Junta de Andalucía, Ronda (Málaga).

Sparks, D.R., and J.C. Malechek. 1968. Estimating percentage dry weight in diets using a microscope technique. J. Range Management 21(4):264-265.

Warren, L.E., D.N. Ueckert, and J.M. Shelton. 1984. Comparative diet of Rambouillet, Barbado and Karakul sheep and Spanish and Angora goats. J. Range Management 37(2):172-180.

Zanine, A.M., E.M. Santos, D.J. Ferreira, A. Lora, and G. Lora. 2006. Comportamento ingestivo de ovinos e caprinos em pastagens de diferentes estruturas morfológicas. Revista Electrónica de Veterinaria (REDVET) 7(3):1-10. 